\title{
二重鋼管の補剛性能に関する研究 \\ A STUDY ON STIFFENING CAPACITY OF DOUBLE-TUBE MEMBERS
}

\author{
桑原 進*, 多田元英**, 米山隆也***, 今井克彦**** \\ Susumu KUWAHARA, Motohide TADA, Takaya YONEYAMA and Katsuhiko IMAI
}

The double-tube member presented here consists of outer circular tube and inner circular tube which has shorter length than the outer. The outer tube resists axial force and inner tube restrains lateral displacement of outer tube by bending resistance. The results obtained from the axial loading test to confirm laterally stiffening effect of inner tube are as follows. Inner tube with suitable strength and stiffness prevents buckling of the member in elasto-plastic range and the remarkable axial deformation of the member is obtained beyond yield load without any decrease of loading both under monotonic and repeated loading.

Keywords : buckling, stiffening, steel tube

座屈, 補剛, 鋼管

\section{1. 序}

鋼構造物の設計において，座屈現象は接合部にならん で特に注意を払わなければならない点の一つである。す なわち, 設計者が定めた部材応力を達成するべく, いか に適切に部材を補剛するかが重要となる。従来, 軸力材 の補剛は補助部材を材の中間に離散的に設定し, 座屈長 さを減ずる方法が多く採用されている。

座屈現象は座屈たわみ角公式に見られるように圧縮軸 力による部材の曲げ剛性の喪失が原因と解釈できる。し たがって，王縮部材に沿って軸力を負担しない材を設け れば，この部材は圧縮部材の軸力にかかわらず曲げ剛性 を保持し，補剛材として有効に機能すると考えられる。 このような補剛方法は前述の方法と異なり, 補剛材が主 材と同一軸上にあること，主材を全長にわたって連続的 に補剛するため座屈することなく降伏応力まで保証し得 ることが特徴であり，角形鋼管や平鋼の周囲をノンフリ クション処理し, $\mathrm{RC}$ で被覆したアンボンドブレース ${ }^{1) \sim 4}$ もこの発想による補剛方法の一つと考えられる。

本研究ではこの考えに基づき，図一1のように鋼管内 部にもう一本の鋼管を挿入し，外管を軸力材，内管を補 剛材とした二重鋼管を提案する。この二重鋼管は内管を

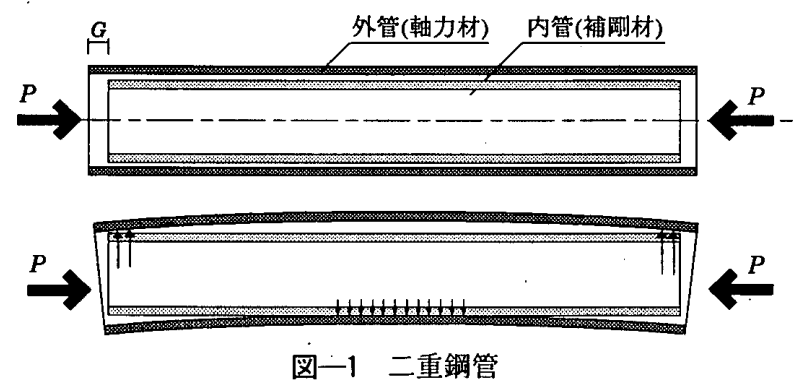

外管よりも短くして端部にクリアランス $G$ を設け, 軸 力を外管のみが負担するようにし，圧縮荷重を受けて外 管が屈曲しようとすると内管に接触し, 内管に横変形が 生じて補剛力が発生し, 外管の屈曲に抵抗しようとする ものである。本論ではこの二重鋼管の全体座屈に対する 補剛条件を導き，それを実験的，および解析的に検証す る。

\section{2. 二重鋼管の補剛条件}

二重鋼管と同様の補剛機構を有するアンボンドブレー スに対して, 藤本らおよび長尾らは補剛材である RC 被覆材の必要曲げ強度と曲げ剛性を補剛材の曲げモーメ ントの釣合式と合成系の座屈荷重から，それぞれ別途に

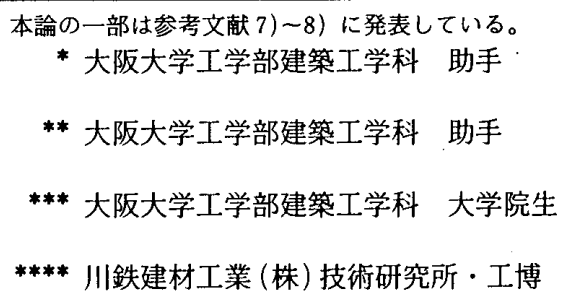

Research Assoc., Dept of Architectural Engineering, Faculty of Engineering, Osaka Univ.

Research Assoc., Dept of Architectural Engineering, Faculty of Engineering, Osaka Univ.

Graduate Student, Dept of Architectural Engineering, Faculty of Engineering, Osaka, Univ.

Technical and Research Laboratories, Kawatetsu Steel Products Corp., Dr. Eng. 


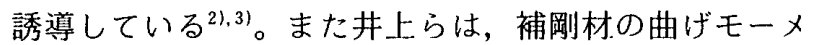
ントの釣合式より補剛材の剛性条件と強度条件を, 補剛 力分布を介して関連したものとして誘導している4!。本 章では後者の考えを二重鋼管に適用し,補剛条件を示す。

軸力材となる外管は完全弾塑性型の荷重一変形特性を 有すると仮定し, 図一2(a) のように両端ピン支持の外 管が軸方向に圧縮荷重を受ける場合を考える。外管内径 と内管外径の差 $e$ だけ外管に横たわみが生じると, 図 -2(b) のように外管が内管に接触し, 補剛力が発生す る。図一2(c) のように外管が全断面降伏し，曲げ岡性 がゼロになった状態を考える。図中， $N_{y}$ は外管の降伏 軸力， $v$ は中央横たわみを示す。この時の内管の中央曲 げモーメント ${ }_{i} M_{c}$ に関する釣合式は以下のように表され る。

$$
{ }_{i} M_{c}=N_{\mathrm{s}}(v+e)
$$

また，二重鋼管には不可避の初期不整が存在することが 考えられるから，これを内管の中央初期たわみ $v_{0}$ とし て表現すると（1）式は以下のようになる。

$$
{ }_{i} M_{c}=N_{y}\left(v+e+v_{0}\right)
$$

図一2(c) のように補剛力を等分布荷重 $q$ であると仮定 すると，（2）式および内管の中央曲げモーメント-中央 横たわみ関係より, 補剛条件として以下のような必要曲 げ強度一曲げ剛性関係を得る。

$$
m_{o} l \geq \frac{e+v_{0}}{1-\frac{C_{s s}}{k_{b}}} \quad C_{s s}=\frac{5}{48}
$$

ただし， $m_{b}, k_{b}$ はそれぞれ内管の無次元化曲げ強度, 曲げ剛性であり次式で与えられる。

$$
m_{b}=\frac{i M_{b}}{N_{y} l} \quad k_{b}=\frac{{ }_{i} E_{i} I}{N_{y} l^{2}}
$$

ただし， ${ }_{i} M_{b}$ は内管の曲げ強度, ${ }_{i} E_{i} I$ は内管の曲げ㴊性, $N_{y}$ は外管の降伏軸力, lは材長である。内管の曲げ強 度は剛性を維持する限界値として定義する必要があるた め，以下では ${ }_{i} M_{b}$ に内管の降伏モーメントを採用する。

補剛力分布を中央集中荷重, sin 波形分布とすると, それぞれ（2）式の係数 $C_{s s}$ は以下の值となる4)。

$$
C_{s r}=\frac{1}{12} \text { (中央集中荷重) } \quad C_{s r}=\frac{1}{\pi^{2}}(\sin \text { 波形分布) }
$$
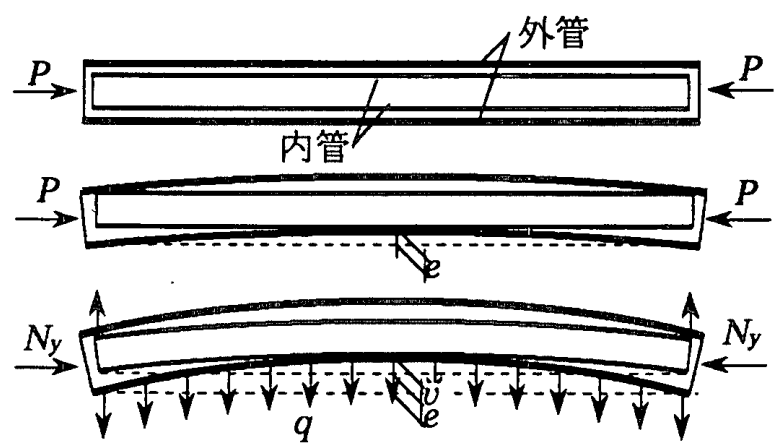

$$
\text { 図一2 二重鋼管の補剛力発生機構 }
$$

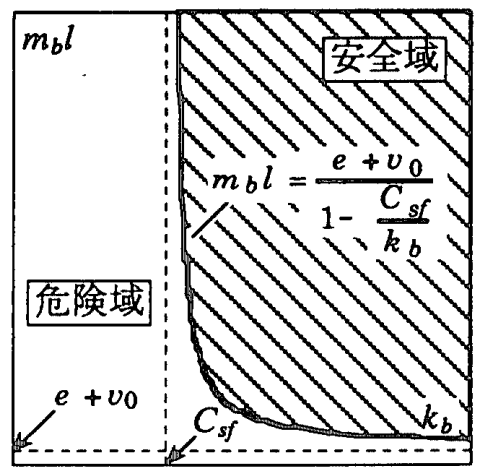

图一3 内管曲げ強度および用性の安全域と危険域

(3) 式を等式とし, 縦軸に $m_{b} l$, 横軸に $k_{b}$ をとつ て図示すると図一 3 の $m_{b} l=e+v_{0}, k_{b}=C_{s f}$ の漸近線 を有する曲線を得る。この曲線より右上の斜線部分に内 管の曲げ強度, 曲げ剛性が位置する場合は（3）式の補 剛条件を満足することになり，内管は補剛材として有効 に機能することになる。以降ではこの曲線の右上斜線部 を安全域，左下の補剛条件を満足しない領域を危険域と 称する。図より補剛材の曲げ強度が大きい場合には，高 い曲げ㴊性を必要としないことが分かる。必要曲げ剛性 の下限は補剛力分布形状によって決定される $C_{s f}$ に よって定まる。今回考慮した補剛力分布の内 $C_{s s}$ が最 大となるものは等分布荷重であり，以下では安全側を考 慮して $C_{s f}=5 / 48$ とする。また同様に，補剛材の曲げ 剛性が高い場合には，大きな曲げ強度は必要とせず，そ の下限は内外管の隙間 $e+v_{0}$ で定まり補剛力分布の影 響は小さくなることがわかる。

\section{3. 二重鋼管および単鋼管の軸方向載荷実験}

3.1 試験体および実験方法

試験体一覧を表一1に，試験体形状を図一 4 に，また，

表一1 試験体一覧

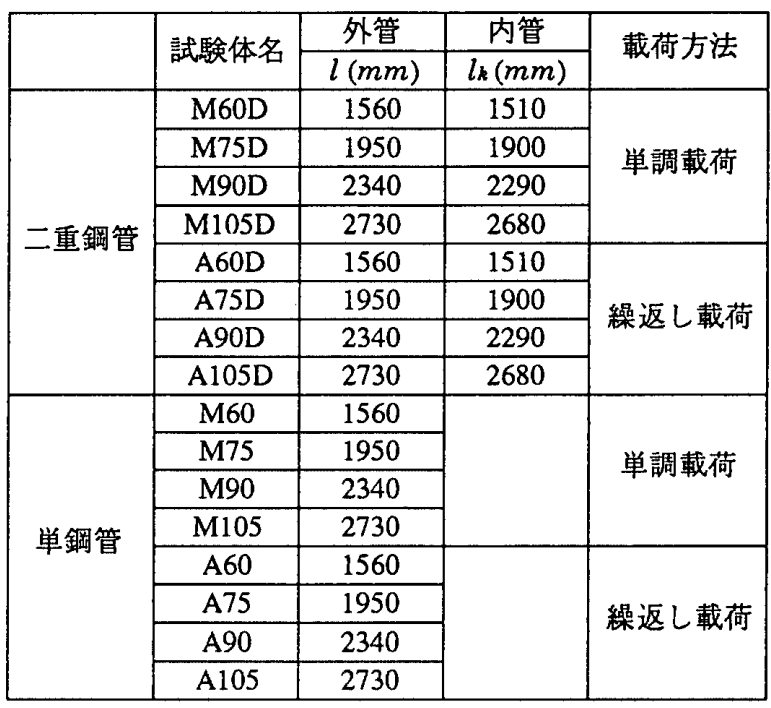

M60D

D：二重鋼管、なし：単鋼管 細長比

$\mathrm{M}$ : 単調載荷、 $\mathrm{A}:$ 繰返し載荷 


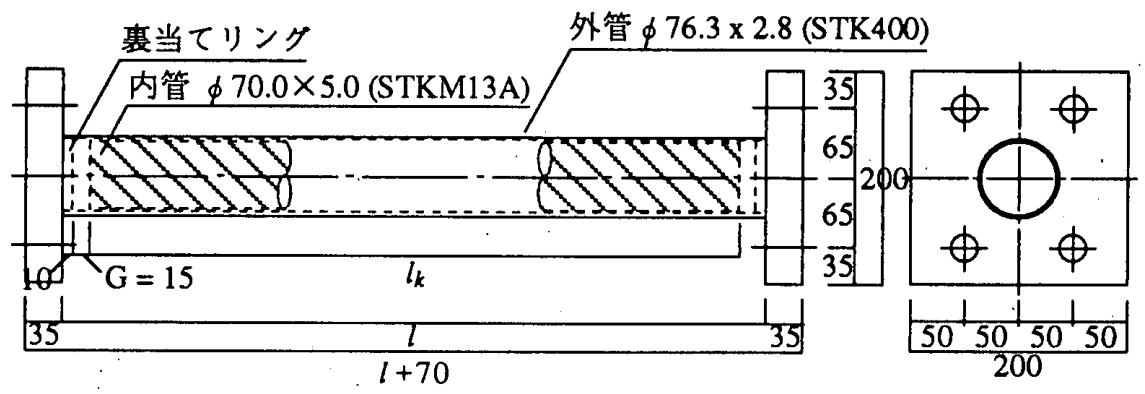

図一4 試験体形状および寸法

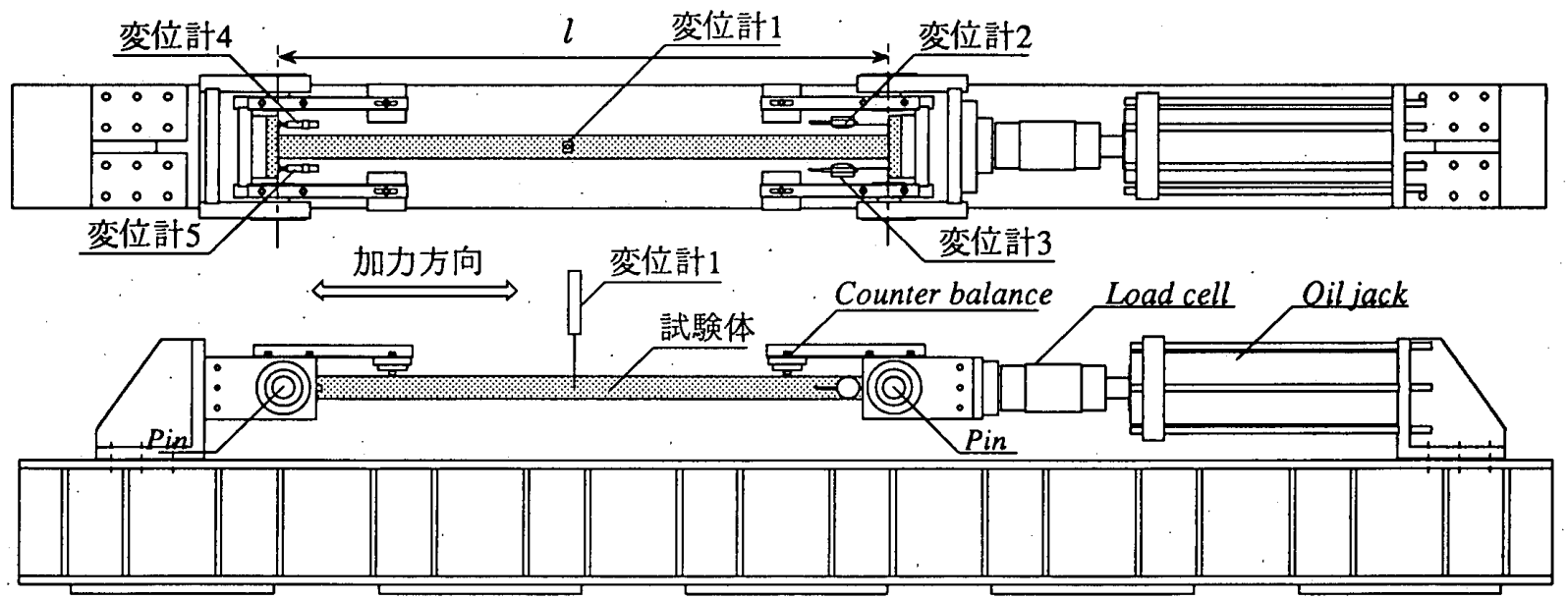

図一5 実験載荷装置

図一 5 に実験載荷装置を示す。試験体数は合計 16 体で あり, 実験変数は細長比, 内管の有無, および載荷方法 である。載荷方法は単調および絽返し軸方向載荷とする。 軸力材となる外管はいずれも $\phi 76.3 \times 2.8(\mathrm{~mm})$ の冷 間成形鋼管を使用する。鋼管両端部には鋼管をピン治具 とボルト 4 本で接合するためエンドプレートを溶接す る。鋼管の溶接シームは鉛直方向の座屈に影響を及ぼさ ないように水平方向に位置させる。図一5に示すように ピンの回転中心はエンドプレートと鋼管の接する面に一 致するのでエンドプレート内法間距離が座屈長さとな $ろ^{5 !}$ 。二重鋼管には内管として $\phi 70.0 \times 5.0(\mathrm{~mm})$ を使 用し，軸力が作用しないようにするため材長を外管より 短くし，端部にクリアランスとして $15 \mathrm{~mm}$ ずつ, 合計 $30 \mathrm{~mm}$ 設けている。本実験では内管は単に外管内部に 挿入されるのみで, 特に固定されていない。二重鋼管の 実際の適用に際しては, 材中央部の外管に穴をあけプラ グ溶接することで内管を固定する。外管と内管の隙間は 公称値で $0.7 \mathrm{~mm}$ であり, 細長比 $60,75,90,105$ の試 験体それぞれの材長の $1 / 2229,1 / 2786,1 / 3343$, $1 / 3900$ となる。

図一 5 に示すように，試験体をエンドプレート内面を 中心として鉛直方向に回転するピン治具で支持し，ロー 快ルを介して 200 ton オイルジャッキにより軸方向加 力する。繰返し載荷は図一6 の載荷計画に基づいて行う。 また，変位計 1 により鋼管の横たわみを，変位計 $2 \sim 5$

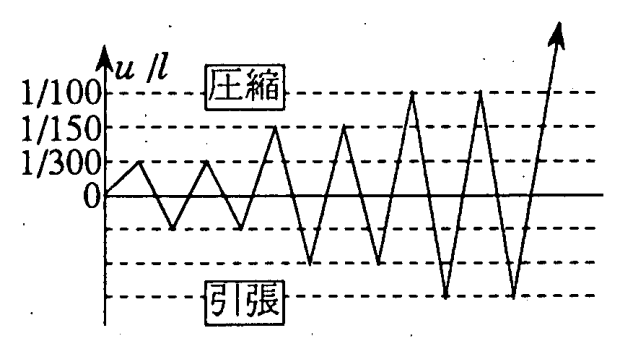

図一6 載荷計画

により鋼管の軸方向変位を測定する。

端部は回転摩擦力をできる限り低減するようピンの軸 受け部にベアリングを使用する。また，ピン治具および 試験体端部のエンドプレートの自重により回転モーメン ト $0.28 \mathrm{t} \cdot \mathrm{cm}$ が生じるため，これと釣合うようにカウン ターバランスを設ける。

\section{2 部材の機械的性質および断面諸量}

素材試験として短柱圧縮試験，ならびに引張試験を 行った。短柱圧縮試験体の材長は鋼管径の 3 倍とし, 外 管に対応する $\phi 76.3 \times 2.8$ を $229 \mathrm{~mm}$ ，内管に対応する $\phi 70.0 \times 5.0$ を $210 \mathrm{~mm}$ とした。引張試験は短柱圧縮試 験体と同じ長さの鋼管に引張るための治具を端部に溶接 して行った。鋼材種別は外管が STK 400, 内管が STKM 13Aである。降伏応力度の算定には $0.2 \%$ offset 值を用いた。

表一 2 に試験体の断面諸量を示す。本実験では圧縮載 荷時の座屈が問題となるため, 外管については短柱圧縮 
表一2 試験体断面諸量

\begin{tabular}{|c|c|c|c|c|c|c|c|c|c|c|c|c|c|}
\hline & $\begin{array}{l}\text { 試驗 } \\
\text { 体名 }\end{array}$ & & $\underset{(m m)}{l}$ & $\underset{(m m)}{D}$ & $\underset{(m m)}{t}$ & $\underset{\left(\mathrm{mm}^{2}\right.}{A}$ & $\mid \begin{array}{c}I \\
\left.\mathrm{~cm}^{4}\right)^{4}\end{array}$ & $\underset{\left(\mathrm{cm}^{3}\right)}{Z}$ & $\underset{\mathrm{cm}}{\mathrm{cm}{ }^{3}}$ & $\begin{array}{l}\sigma_{y} \\
\left(\mathrm{~cm}^{2}\right)\end{array}$ & $\begin{array}{c}N_{y} \\
(\theta)\end{array}$ & $\begin{array}{l}M_{y} \\
(1 \mathrm{~cm})\end{array}$ & $\begin{array}{l}M_{p} \\
(\mathrm{fcm})\end{array}$ \\
\hline & M60 & & 1558 & 76.3 & 2.64 & 610 & 41.5 & 10.9 & 14.3 & 3.62 & 22.1 & 39.3 & 51.8 \\
\hline & M75 & & 1950 & 76.3 & 2.64 & 611 & 41.5 & 10.9 & 14.3 & 3.53 & 21.6 & 38.4 & 50.6 \\
\hline & M90 & & 2338 & 76.4 & 2.64 & 611 & \begin{tabular}{|l|}
41.6 \\
\end{tabular} & 10.9 & 14.4 & 3.53 & 21.6 & 38.5 & 50.7 \\
\hline & M105 & & 2728 & 76.3 & 2.64 & 611 & 41.5 & 10.9 & 14.3 & 3.53 & 21.6 & \begin{tabular}{|l|}
38.4 \\
\end{tabular} & 50.6 \\
\hline & A60 & & 1558 & 76.3 & 2.64 & 610 & 41.4 & 10.9 & 14.3 & 3.62 & 22.1 & 39.3 & 51.8 \\
\hline & A75 & & 1949 & 76.2 & 2.65 & 613 & 41.5 & 10.9 & 14.4 & 3.60 & 22.1 & \begin{tabular}{|l|}
39.2 \\
\end{tabular} & 51.7 \\
\hline & A90 & & 2340 & 76.3 & 2.65 & 613 & 41.7 & 10.9 & 14.4 & 3.60 & 22.1 & \begin{tabular}{|l|}
39.3 \\
\end{tabular} & 51.8 \\
\hline & A105 & & 2730 & 76.3 & 2.64 & 610 & 41.4 & 10.9 & 14.3 & 3.64 & 22.2 & 39.5 & 52.1 \\
\hline \multirow{8}{*}{ 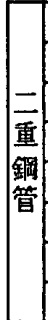 } & M60D & A & 1559 & 76.1 & 2.65 & 612 & \begin{tabular}{|l|}
41.3 \\
\end{tabular} & 10.9 & 14.3 & 3.60 & 22.0 & \begin{tabular}{|l|}
39.1 \\
\end{tabular} & 51.5 \\
\hline & M75D & A & 1949 & 76.3 & 2.64 & 611 & 41.5 & 10.9 & 14.3 & 3.53 & 21.6 & 38.4 & 50.6 \\
\hline & M90D & A & 2338 & 76.5 & 2.64 & 612 & 41.8 & 10.9 & 14.4 & 3.53 & 21.6 & 38.6 & 50.8 \\
\hline & M105D & A & 2730 & \begin{tabular}{|l|}
76.4 \\
\end{tabular} & 2.64 & 611 & \begin{tabular}{|l|}
41.6 \\
\end{tabular} & 10.9 & 14.4 & 3.53 & 21.6 & \begin{tabular}{|l|}
38.5 \\
\end{tabular} & 50.7 \\
\hline & $\mathrm{A} 60 \mathrm{D}$ & A & 1560 & 76.3 & 2.64 & 610 & 41.5 & 10.9 & 14.3 & 3.62 & 22.1 & 39.3 & 51.8 \\
\hline & A75D & $\mathrm{A}$ & 1949 & 76.3 & 2.64 & 610 & \begin{tabular}{|l|}
41.4 \\
\end{tabular} & 10.9 & 14.3 & 3.62 & 22.1 & \begin{tabular}{|l|}
39.3 \\
\end{tabular} & 51.8 \\
\hline & A90D & $\mathbf{D}$ & 2340 & 76.3 & 2.64 & 610 & \begin{tabular}{|l|}
41.4 \\
\end{tabular} & 10.9 & 14.3 & 3.59 & 21.9 & 39.0 & 51.3 \\
\hline & A105D & B & 2729 & 76.3 & 2.64 & 610 & \begin{tabular}{|l|}
41.4 \\
\end{tabular} & 10.9 & 14.3 & 3.64 & 22.2 & 39.5 & 52.0 \\
\hline 内 & 内管A & & & 70.0 & 4.98 & 1017 & 54.1 & 15.4 & 21.1 & 3.33 & \begin{tabular}{|l|}
33.9 \\
\end{tabular} & \begin{tabular}{|l|}
51.4 \\
\end{tabular} & 70.2 \\
\hline 管 & 内管B & & & 70.0 & 5.08 & 1036 & \begin{tabular}{|l|}
54.9 \\
\end{tabular} & 15.7 & 21.5 & 3.37 & 34.9 & 52.9 & 72.3 \\
\hline
\end{tabular}

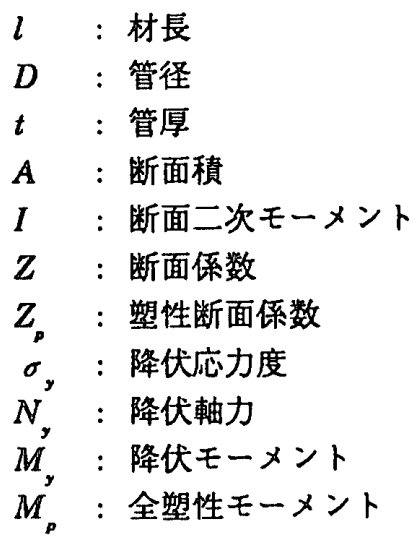

表一3 実験結果

\begin{tabular}{|c|c|c|c|c|c|c|c|c|}
\hline & 試験体 & $P_{\max }$ & $\mid \begin{array}{l}u_{\max } \\
(m m)\end{array}$ & $\left|\begin{array}{l}v_{\max } \\
(m m)\end{array}\right|$ & $\frac{P_{\max }}{N_{y}}$ & $\frac{u_{\max }}{u_{y}}$ & $\frac{v_{\max }}{l}\left(\times 10^{-2}\right)$ & $\mid$ \\
\hline \multirow{8}{*}{$\begin{array}{l}\text { 年 } \\
\text { 㖉 } \\
\text { 管 }\end{array}$} & M60 & 19.10 & 2.44 & 1.80 & 0.87 & 0.91 & 0.11 & $\bar{D}$ \\
\hline & M75 & 16.45 & 2.59 & 4.00 & 0.76 & 0.79 & 0.21 & $\overline{\mathrm{D}}$ \\
\hline & M90 & 14.35 & 2.68 & 2.40 & 0.67 & 0.68 & 0.10 & $\bar{D}$ \\
\hline & M105 & 11.25 & 2.41 & 5.40 & 0.52 & 0.53 & 0.20 & D \\
\hline & $\mathrm{A} 60$ & \begin{tabular}{|l|}
19.05 \\
\end{tabular} & 2.42 & 2.50 & 0.86 & 0.90 & 0.16 & $\bar{U}$ \\
\hline & A75 & 17.70 & 2.69 & 5.80 & 0.80 & 0.81 & 0.30 & $\bar{U}$ \\
\hline & A90 & 14.95 & 2.80 & 2.00 & 0.68 & 0.70 & 0.09 & $\mathrm{D}$ \\
\hline & A105 & 11.45 & 2.45 & 9.90 & 0.52 & 0.52 & 0.36 & $\mathrm{U}$ \\
\hline \multirow{8}{*}{$\begin{array}{l}\text { 重 } \\
\text { 铜闺 } \\
\text { 管 }\end{array}$} & M60D & 31.30 & 29.19 & 0.10 & 1.42 & 10.92 & 0.01 & 1 \\
\hline & M75D & 25.85 & 24.71 & 23.10 & 1.20 & 7.54 & 1.19 & 1 \\
\hline & M90D & 20.50 & 7.45 & 24.60 & 0.95 & 1.90 & 1.05 & $\bar{D}$ \\
\hline & M105D & 17.80 & 4.38 & 7.00 & 0.82 & 0.95 & 0.26 & D \\
\hline & A60D & 25.00 & 15.57 & 4.10 & 1.13 & 5.79 & 0.26 & 42 \\
\hline & A75D & 24.90 & 18.17 & 13.20 & 1.13 & 5.41 & 0.68 & 43 \\
\hline & A90D & 21.40 & 5.77 & 16.30 & 0.98 & 1.44 & 0.70 & $\mathrm{D}$ \\
\hline & $\mathrm{A} 105 \mathrm{D}$ & 19.55 & 4.58 & 8.30 & 0.88 & 0.97 & 0.30 & D \\
\hline
\end{tabular}

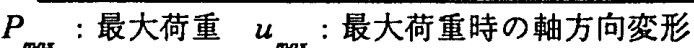

$v_{\text {max }}$ : 最大荷重時の年央横たわみ $\mathrm{U}:$ 鉛直上方向に曲げ 座屈した場合

$\mathrm{D}$ : 鉛直下方向に曲げ座屈した場合

*1:座屈せず端部局部座屈により耐力減少

*2: 座屈せず $l / 100$ のループ2回目で端部局部座屈により耐

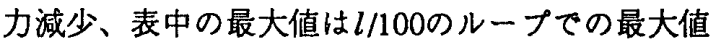

*3: 座屈せず $l / 100$ のループ1回目で端部局部座屈により耐 力減少、最大值は局部座屈発生時

試験より得られた降伏応力度を採用する。軸力の作用し ない曲げ材である内管の降伏応力度は, 短柱圧縮試験お よび引張試験より得られた降伏応力度の平均值とする。

\section{3 実験結果および考察}

表一 3 に実験結果を示す。図一7に単調圧縮載荷によ る荷重-軸方向変形関係を, 図一 8 に荷重-横たわみ関係 を細長比ごとに示す。荷重-軸方向変形関係の横軸, 縦 軸はそれぞれ試験体外管の降伏縮み $u_{y}$, 降伏軸力 $N_{y}$ に
より，また，荷重一横たわみ関係の横軸，縦軸はそれぞ れ試験体の材長 $l$, 降伏軸力 $N_{\mathbf{y}}$ により無次元化されて いる。いずれも圧縮載荷方向を正とする。図中, 実線は 二重鋼管を, 点線は単鋼管を示し, Wはそれぞれの最大 荷重レベルを示し，は局部座屈の発生時点を示す。ま た，M60DおよびM75Dの トに接触したことにより荷重が上昇した位置を示してい る。図一9にはA 60,A60D,A90D試験体の繰返し載 荷による荷重一軸方向変形関係を示す。縦軸, 横軸, お よび図中の記号は図一7 と同じである。また，比較のた めに点線で各試験体の単調載荷実験結果を付記する。

単調圧縮載荷実験の結果，すべての単鋼管試験体が, 試験体中央部分において曲げ座屈を生じた。曲げ座屈後 は荷重の低下とともに変形が進み，M60では曲げ座屈 を生じた中央部分の凹側部分において局部座屈が発生し た。繰返し載荷の場合も単調載荷と同様に, 処女載荷の 振幅 $u / l=1 / 300$ のループですべての単鋼管試験体が, 試験体中央部分において曲げ座屈を生じ，その後のルー プでは劣化型の履歴性状を示した。図一10に縦軸に実 験で得られた座屈応力度を, 横軸に細長比をとって示す。 また，座屈耐力曲線を以下に示す Euler 式, Johnson 式 によって求め，同図に付記する。ただし，Johnson 式は 降伏応力度を頂点として Euler 曲線と接する放物線で あり，次式における係数 $k$ は降伏応力度によって異な る。

$$
\text { Euler 式 }: \sigma_{c r}=\pi^{2} E / \lambda^{2}
$$

Johnson 式: $\sigma_{c r}=\sigma_{y}-k \lambda^{2}$

いずれの実験結果も座屈耐力曲線と良く対応しており, 本実験の信頼性が確認できる。

一方，二重鋼管試験体は同細長比の単鋼管と比較して 耐力および軸方向変形能が大きくなっていることがわか 

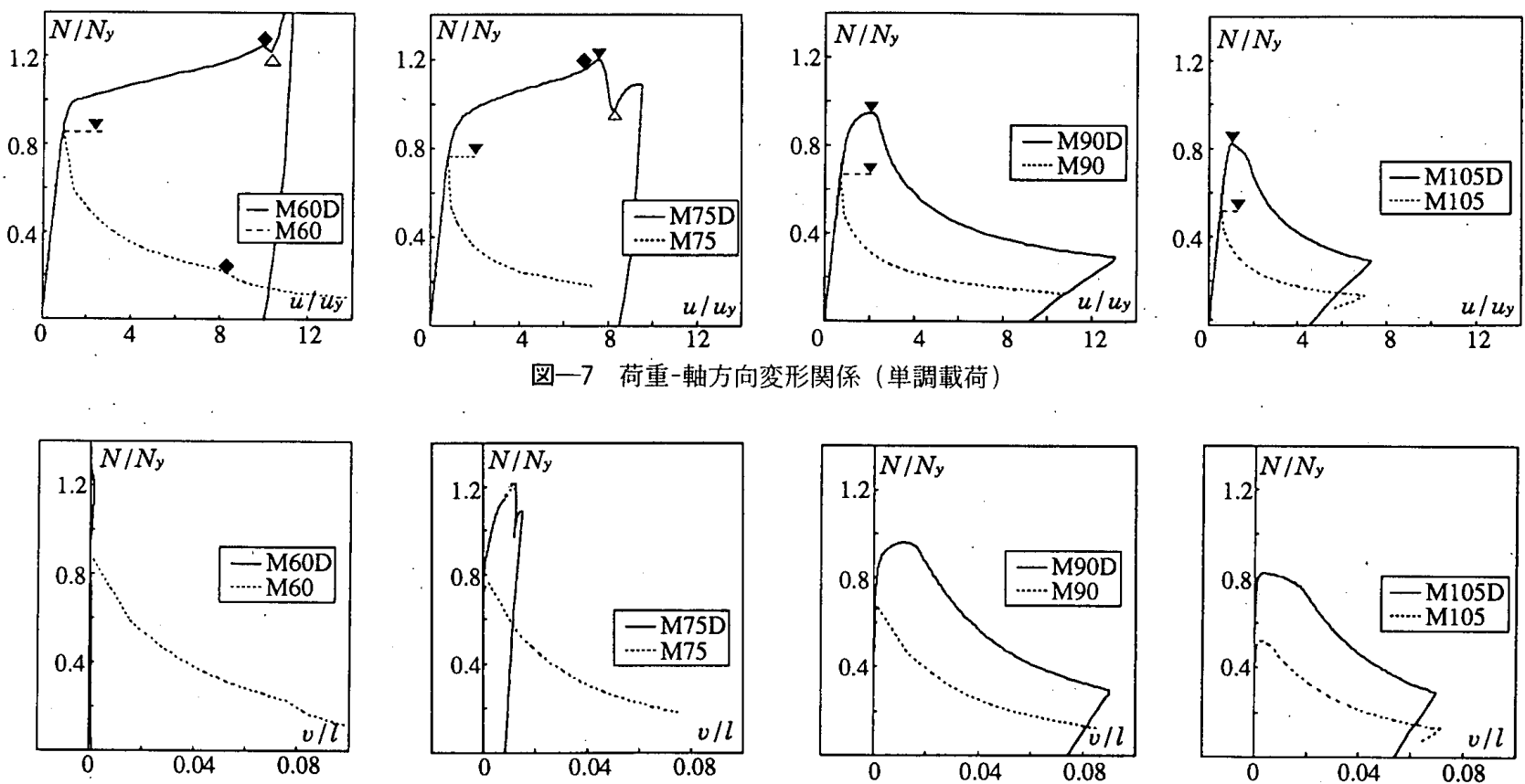

図一8 荷重-横たわみ関係（単調載荷）
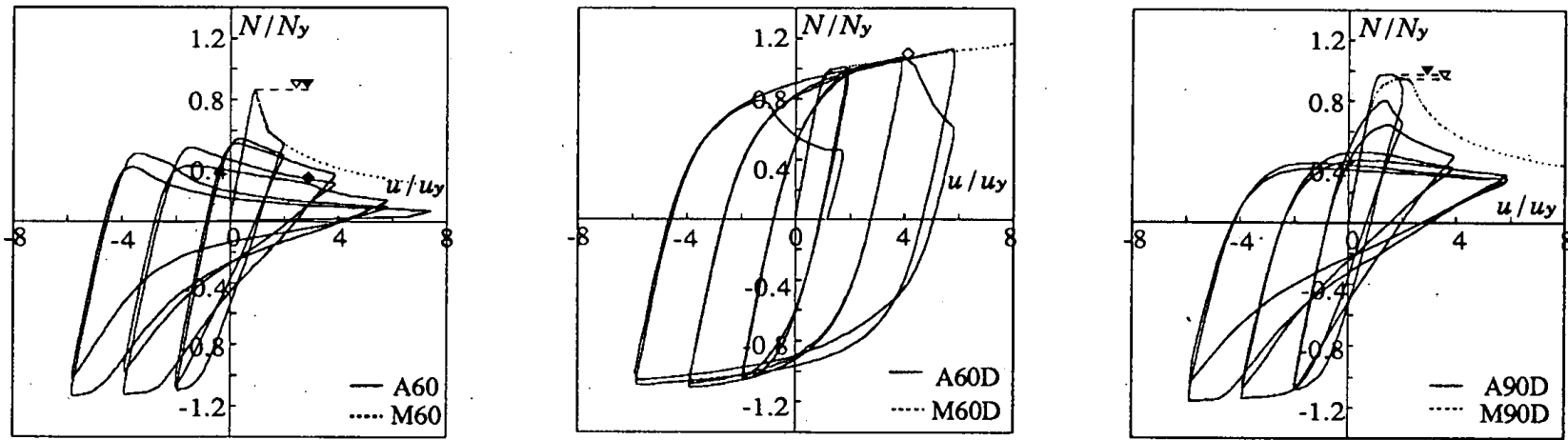

図-9 荷重-軸方向変形関係（繰返し載荷の例）

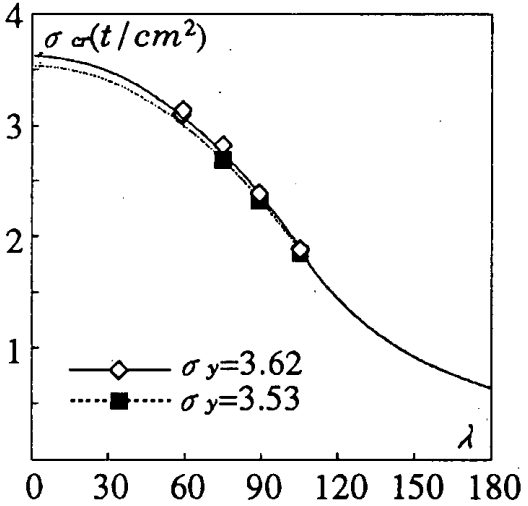

図一10 座屈耐力曲線比較図

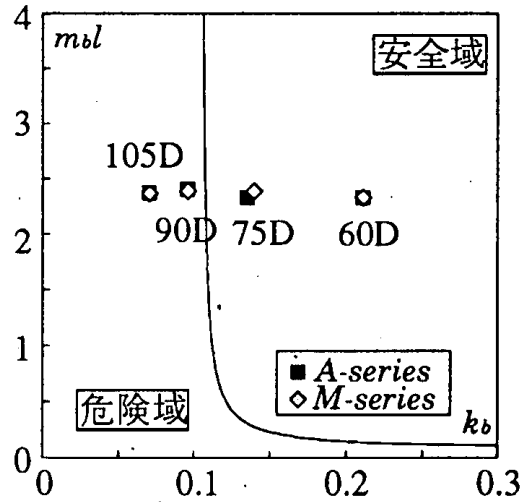

図一11 必要曲げ強度-曲げ岡性関係
表一4 内管の無次元化曲げ用性・強度

\begin{tabular}{|c|c|c|c|}
\hline 試験体名 & $k b$ & $m b$ & $m b l$ \\
\hline M60D & 0.212 & 0.015 & 2.333 \\
\hline M75D & 0.138 & 0.012 & 2.384 \\
\hline M90D & 0.096 & 0.010 & 2.380 \\
\hline M105D & 0.071 & 0.009 & 2.383 \\
\hline A60D & 0.211 & 0.015 & 2.329 \\
\hline A75D & 0.135 & 0.012 & 2.331 \\
\hline A90D & 0.096 & 0.010 & 2.416 \\
\hline A105D & 0.070 & 0.009 & 2.382 \\
\hline
\end{tabular}

る。特に細長比が 60,75 のM60D，M75D試験体にお いては座屈することなく軸方向に大きな塑性変形を示し た。これらの試験体では最終的には端部において局部座 屈を生じ，その後耐力が減少した。細長比が 90 および 105 のM90D，M105 D 試験体はあまり軸方向に塑性変 形せず座屈し, 荷重が低下した。以上の傾向は繰返し載
荷の場合も同様であり，A60D，A75D試験体は座屈す ることなく塑性変形し，端部に局部座屈が発生するまで は安定した紡錘形の履歴性状を示した。それに対し A 90 $\mathrm{D}, \mathrm{A} 105 \mathrm{D}$ 試験体は処女載荷の振幅 $u / l=1 / 300$ のルー プで座屈を生じ以降のループでは図一9のA90Dのよう な劣化形の履歴性状を示した。図一11に（3）式の必 
要曲げ強度-曲げ剛性関係を示す。ただし，内管と外管 の隙間 $e=0.7(\mathrm{~mm}), v_{0}=0$ とする。また, 表一4には 試験体内管の無次元化曲げ剛性 $k_{b}$, 無次元化曲げ強度 $m_{b}$ ，および $m_{b} l$ を示し，これを図一11中に付記する。 図より細長比 60 および 75 の試験体が安全域，細長比 90 および 105 の試験体が危険域に存在し，実験結果は これに良く対応している。

\section{4. 弾塑性解析による補剛効果の検証}

\section{1 解析条件}

弾塑性解析には幾何学的非線形を考慮した一次元有限 要素法を用い, 非線形剛性方程式の数值解析には增分摄 動法 ${ }^{6}$ を用いた。解析条件を以下に示す。

（1）鋼管の断面は図一12 に示す 6 集中線要素モデル とする。図中, $A_{m}$ は各線要素の断面積であり鋼管断面 積の $1 / 6$ とする。

（2）王縮材の弾塑性座屈は材料の接線剛性が大きく影 響するため，応力度一ひずみ度曲線のモデル化はより詳 細なものが必要となる。したがって，本解析では短柱圧 縮試験より得られた曲線をモデル化した四分割の poly linear 型として解析を行った。図一13にモデル化の一 例を示す。破線が短柱圧縮試験結果，実線がモデルであ る。

（3）内管の応力度-ひずみ度曲線は bi-linear 型として ヤング係数 $2100\left(\mathrm{t} / \mathrm{cm}^{2}\right)$ ，ひずみ硬化係数 0.01 とする。 降伏応力度は表一 2 による。

\section{2 解析モデル}

解析対象となる単鋼管は, 図一14 に示す長さ $l$, 中央 初期たわみ $v_{0} / 10000$ を有する王縮材である。二重鋼管 の解析モデルを図一 15 に示す。材長 $l$, 初期中央たわみ

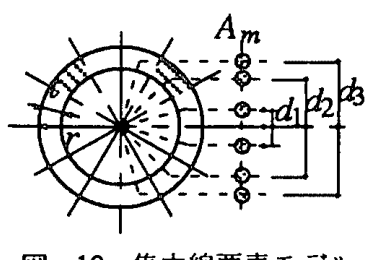

図一12 集中線要素モデル

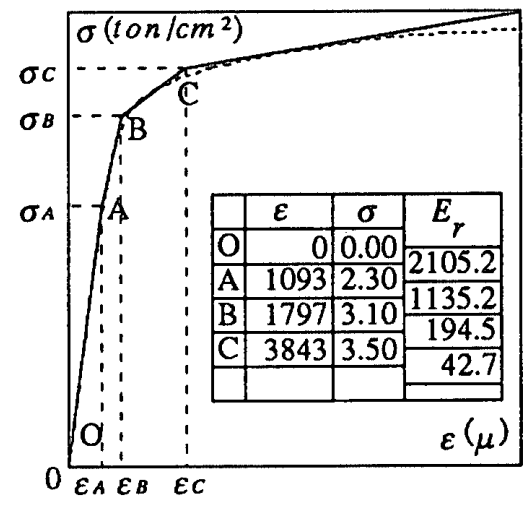

図一13 応力度-ひずみ度曲線モデル

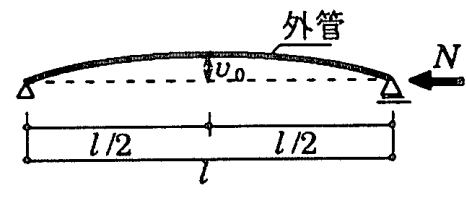

図一14 単鋼管解析モデル

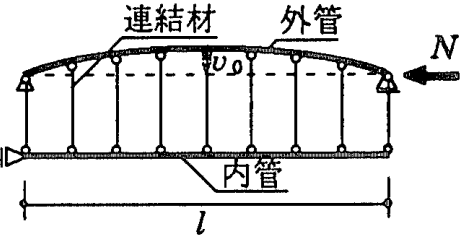

図-15 二重鋼管解析モデル

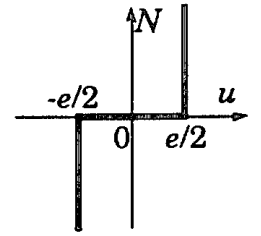

図一16 連結材 $v_{0} / 10000$ を有する外管と, 補剛材となる内管を材長の 8 等分の位置で両端ピンの連結材で連結する。外管が内 管との陌間 $e$ だけ変形した後, 内管に接触し補剛力が 発生する過程をモデル化するために，連結材は図一16 に示すような荷重-変形関係を有する材料として設定す る。

\section{3 解析結果と実験結果との比較}

表一5に単調載荷による単鋼管と二重鋼管の解析結 果, および実験結果の最大耐力と最大耐力時の軸方向変 形との比較を示す。また図一17 に荷重-軸方向変形関係 を示す。図中，実線は解析結果を，点線は実験結果を示 し，座標軸は図一7 と同様である。

解析結果はいずれも単鋼管, 補剛条件を満たす二重鋼 管, 補剛条件を満足しない二重鋼管の性状を良く表現し， 定量的にも実験結果と良く対応している。本解析では外 管端部の局部座屈を考慮していないため，局部座屈発生 に伴う耐力の劣化現象は追跡できないものの, 全体座屈 に関して，解析結果は実験結果をよく追跡している。図 -18にM75Dの解析結果より得られた補剛力 $F_{\text {sts }}$ およ

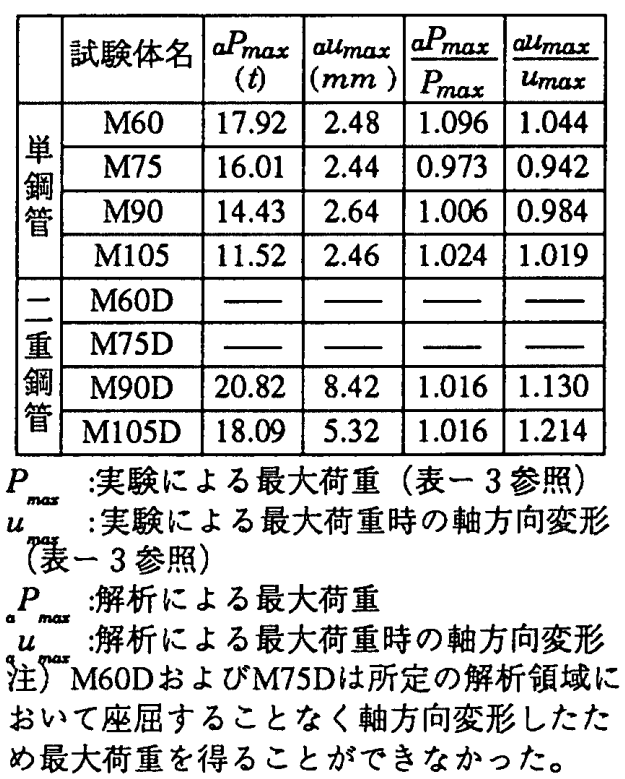



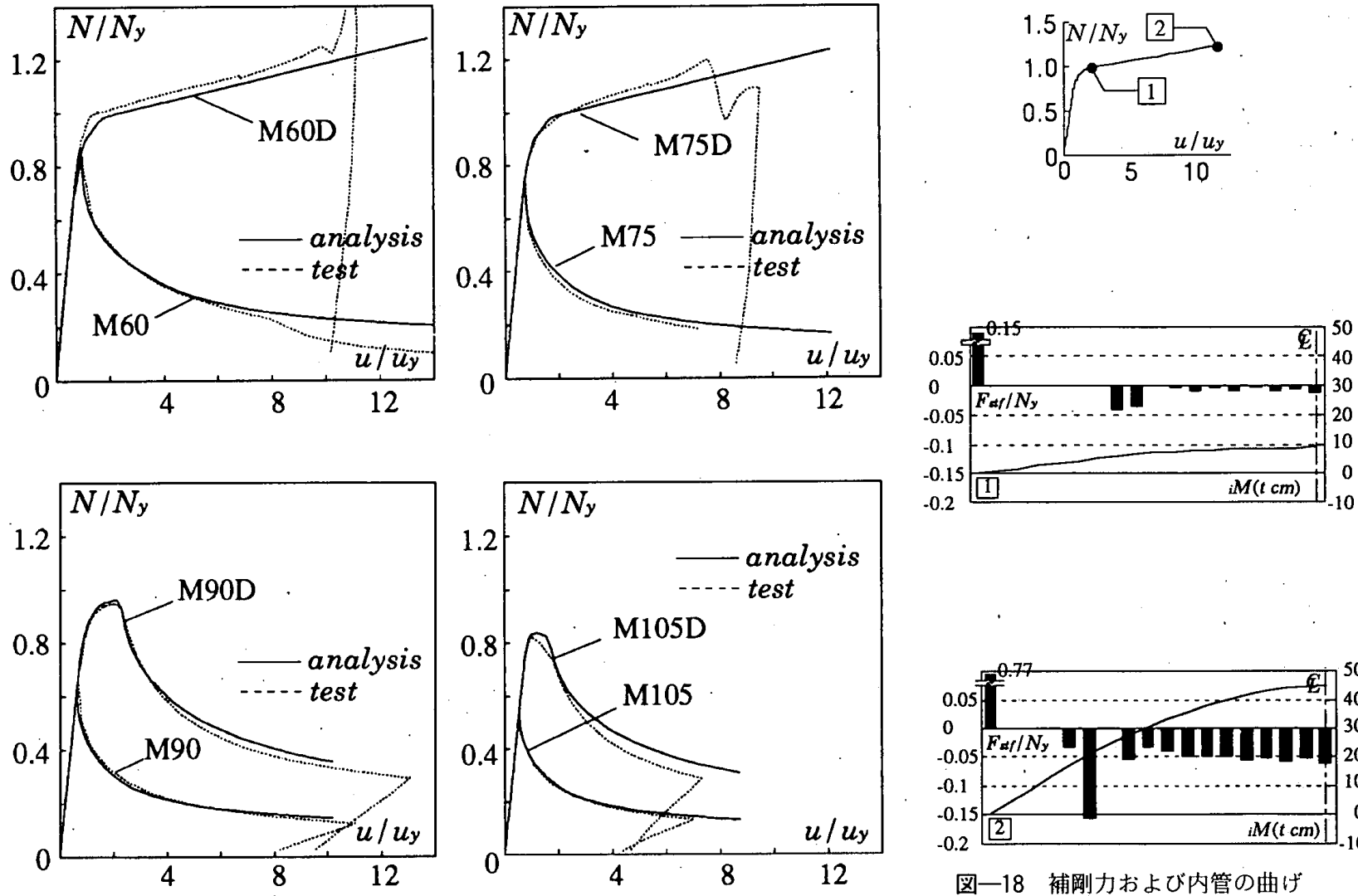

図-17 荷重-軸方向変形関係
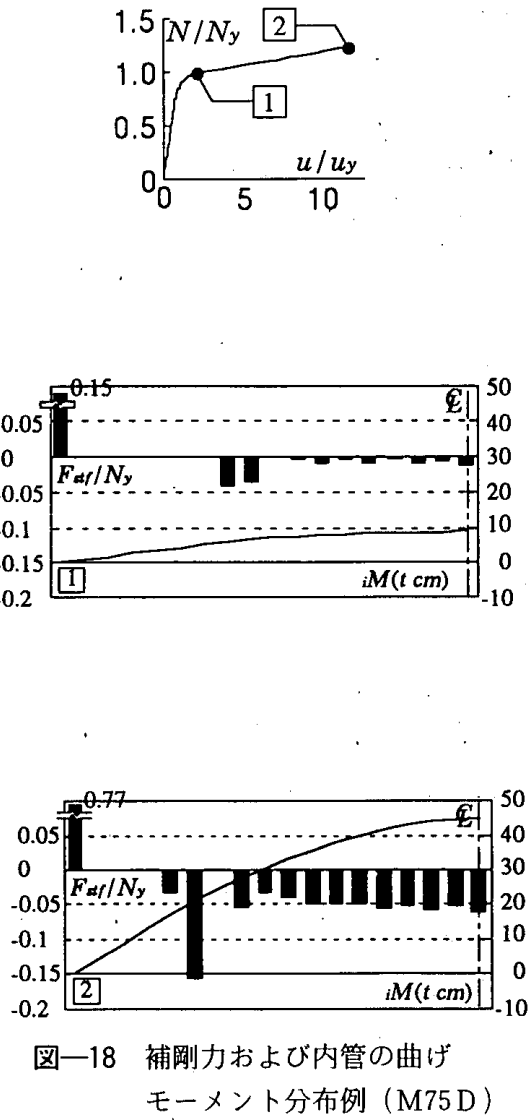

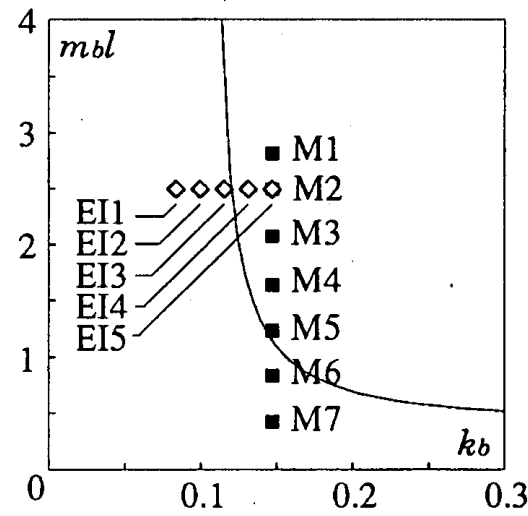

図一19 内管曲げ強度-剛性関係

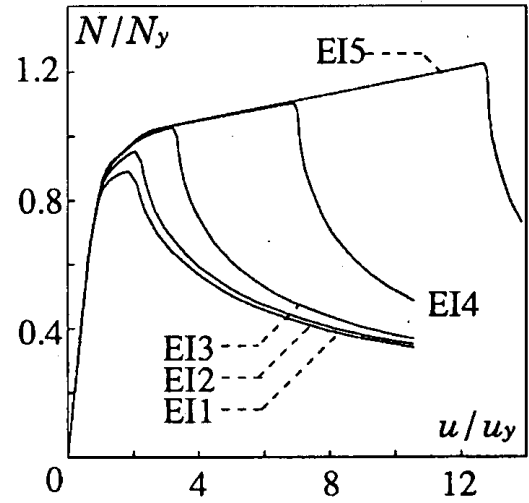

図一20 内管の曲げ剛性による比較

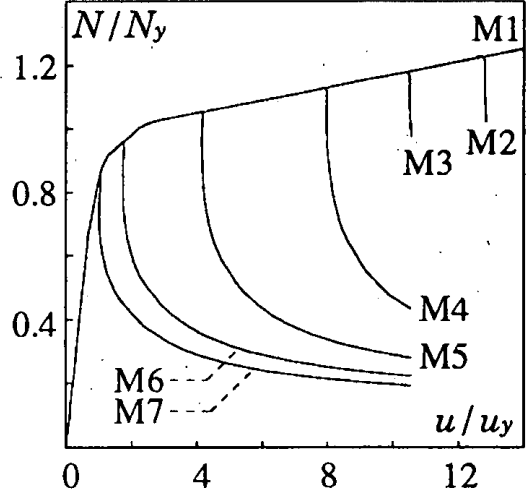

図一21 内管の曲げ強度による比較
び内管の曲げモーメント ${ }_{i} M$ の材長方向の分布を, それ ぞれ棒グラフと折線グラフで示す。ただし，材長方向の 要素分割数は 35 とした。図中一点鎖線は材中央を示す。 1, 2 図は上の荷重一軸方向変形関係上のそれぞれの位置 に対応し，1は外管が降伏軸力に達した位置である。補 剛力は外管の降伏軸力 $N_{y}$ で無次元化している。図より 材中央部ではほぼ均等に補剛力が分布していることがわ かる。

\section{4 補剛材 (内管) の曲げ剛性および曲げ強度の影響} 本節では実験結果との対応によりその有効性が確詡さ れた補剛条件の妥当性をより詳細に評価するために, 内 管の曲げ剛性および曲げ強度を解析変数として解析を行 引。
解析対象は細長比 90 の二重鋼管であり，内管の曲げ 強度を一定とし，曲げ剛性を変化させた EI 1 - EI 5, 曲げ剛性を一定とし，曲げ強度を変化させた M 1 M 7 (M 2 はEI 5 と同一) の計 11 種類である。応力度-ひ ずみ度関係は外管には図一14のモデルを用い，内管に は $\sigma_{y}=3.35\left(\mathrm{t} / \mathrm{cm}^{2}\right)$, ひずみ硬化係数 0.01 の bi-linear 型を用いる。要素分割数は 8 とする。

図一19に（3）式の必要曲げ強度一曲げ剛性関係を 示す。また，同図中に解析対象の二重鋼管 EI 1 EI 5 および M 1 M 7 の曲げ強度と曲げ剛性を図示する。 EI 3 および M 5 が安全域と危険域の境界に位置してい る。図一20に曲げ剛性をパラメーターとした場合の, 図一21に曲げ強度をパラメーターとした場合の荷重-軸 
方向変形関係を示す。図中の軸は図一7 と同様である。 境界領域に位置する EI 3，M 5 を境に軸方向変形性能 が大きく変化していることから，（3）式の補剛条件式 の妥当性が確認できる。また，以上の二重鋼管解析結果 において, 全体座屈の発生が内管中央断面の最外縁要素 の降伏時点と対応しており，2章で曲げ強度を降伏モ一 メントとしたことは妥当であるといえる。

\section{5. 結 論}

本論では，鋼管の座屈を補剛するために鋼管内部にも う一本の鋼管を挿入した二重鋼管を提案し，その補剛性 能を実験的，および解析的に評価した。以下に得られた 結果を要約して示す。

1)二重鋼管および単鋼管の軸方向載荷実験において, 二重鋼管は同細長比の単鋼管と比較して耐力, 軸方向変 形共に増大することを確認した。

2）（3）式の補剛条件を満足する二重鋼管は，単調載 荷により全体座屈することなく軸方向変形を増大させ る。また, 繰返し載荷においても安定した紡鍾形の復元 力特性を示す。

3）（3）式により適正に補剛された二重鋼管は, 軸方 向変形性能が端部の局部座屈で支配される。

4) 一次元有限要素法による弾塑性解析において今回使 用した解析モデルは二重鋼管の性状を良く表現し，二重 鋼管の全体座屈の発生を把握するうえで有効である。

5) 内管の曲げ判性および曲げ強度をパラメーターとし た弾塑性解析からも，（3）式の補剛条件式の妥当性を 確認した。

\section{謝 辞}

本研究に当たっては, 大阪大学 脇山広三教授, 井上 一朗助教授のご指導を得た。また, 実験に際しては大阪
大学大学院生 湯浅友希夫君, 四年生山下仁崇君の助力 を得た。付記して感謝の意を表する。

\section{参考文献}

1）若林 實, 中村 武, 樫原章雄, 森薗哲郎, 横山浩明, 森野捷輔, 宮井清忠, 宮田一実, 小田徹郎：繰返し水平 力を受ける絶縁ブレース内蔵 PC 壁板の弾塑性性状に関 する実験的研究（その 1,2 ) 日本建築学会大会学術講演 梗概集, pp. 1041 1044, 1973. 10.

2）藤本盛久, 和田 章, 佐伯英一郎, 渡辺 厚, 人見泰義 ：鋼管コンクリートにより座屈を拘束したアンボンドブ レースに関する研究, 構造工学論文集, Vol. $34 \mathrm{~B}$, pp. 249 258, 1988. 3.

3）長尾直治，高橋茂治：角形鋼管を鉄筋コンクリートで被 覆したアンボンドブレースの弾塑性性状（その2), 日本 建築学会構造系論文報告集, 第 422 号, pp. $45 \sim 56$, 1991.4.

4) 井上一朗, 沢泉紳一, 東端泰夫, 井ノ上一博: アンボン ド平鋼ブレース内蔵コンクリート壁の座屈補剛設計, 日 本建築学会構造系論文報告集, 第 432 号, pp. $41 \sim 49$, 1992. 2.

5）若林 實, 野中泰二郎, 小城 修, 山本 昇：繰り返し 軸方向力を受ける部材の挙動に関する一実験, 日本建築 学会大会学術講演梗概集, pp. 381～382, 1971.11.

6）石田修三，森迫清貴：增分提動法を導入した一次元複合 非線形有限要素法, 日本建築学会構造系論文報告集, 第 397 号, pp. 73 82, 1989. 3.

7) 脇山広三, 多田元英, 今井克彦, 桑原 進, 米山隆也 : 二重鎆管の補剛効果に関する研究（その1３）, 日本建 築学会学術講演梗概集 構造 II, pp. 1281 1286, 1991.9.

8）脇山広三, 多田元英, 今井克彦, 桑原 進, 米山隆也 : 二重鋼管の補剛効果に関する研究（その $4 \sim 5)$, 日本建 築学会学術講演梗概集 構造 II, pp. 1469 1472, 1992.8.

(1992 年 8 月 27 日原稿受理, 1992 年 12 月 3 日採用決定) 